\title{
Analysis and Acute Toxicity Determination of the Dyestuff in the Effluent of a Textile Manufacturing Company Located In The Eastern Part of Nigeria
}

\author{
Kelle, H.I. ${ }^{1}$, Akpuaka , M.U. ${ }^{2}$ and Oguezi , V.U. ${ }^{3}$ \\ ${ }^{1}$ Chemistry Unit, National Open University of Nigeria, Lagos, Nigeria. \\ ${ }^{2}$ Department of Chemistry, Nnamdi Azikiwe University, Awka, Anambra State, Nigeria. \\ ${ }^{3}$ Department of Chemistry Education, Federal College of Education (Tech.), Asaba, Delta State, Nigeria.
}

\begin{abstract}
In this study the effluent from General Cotton Mill Limited was analysed with respect to the dyestuff. The General Cotton Mill Ltd is an industry involved in textile manufacture which involves a lot of use of dyestuff and since some dyestuff can be environmental hazards, it became necessary to investigate the effluent to ascertain the safety of the effluent. The effluent was extracted with acetone, hexane and petroleum spirit $\left(40^{\circ} \mathrm{C}\right.$ $60^{\circ}$ C).Petroleum spirit was the best extracting solvent. The extract was chromatographically separated and subjected to $U V$ visible, infrared and $L D_{50}$ determination. There were two major dye components in the extract, blue and purple coloured dyes. The UV corresponding to the blue dye is 500nm while that of the purple dye is $520 \mathrm{~nm}$. The functional groups obtained from the IR are primary amide $\left(\mathrm{RCONH}_{2}\right)$, sulphonic group $\left(\mathrm{HSO}_{3}\right)$, vinyl group $\left(-\mathrm{CH}=\mathrm{CH}_{2}\right)$, alkyl chloride $(\mathrm{C}-\mathrm{Cl})$, aromatic amine group. These IR frequencies are in consonant with that found in most fiber reactive dyes. At an $L D_{50}$ test of $500 \mathrm{mg} / \mathrm{kg}$, no death or sign from experimental animal (mice) was observed, which suggest that the extract dye is non toxic.
\end{abstract}

Keywords: Dyestuff, Effluent, Environmental Hazards, $L D_{50}$, Fiber Reactive Dyes

\section{Introduction}

Dye is a natural/synthetic substance that finds application for adding a colour/ altering existing colour shade (1). As a colouring material dyes are used to colour commodities of day to day use and can be applied everywhere including textiles, plastic, paper, food etc. Dyes can be classified as acid, basic, direct, mordant, vat, reactive, disperse, azoic and sulphur dyes $(2,3)$.

The toxic nature of some dyes and intermediates have long been recognized. Acute (short term) effects are generally well known. Chronic (long term) effects, on the other hand, frequently do not become apparent until after many years of exposures $(4,5)$. Statistically higher incidences of benign and malignant tumours, especially in the bladders of workers exposed to certain intermediates and dyes, were recorded in dye producing countries during the period 1930-1960 (4, 5). Many of the dyes used for colouring may form amines ( break down products) under reductive conditions, which have carcinogenic and mutagenic properties. The most problematic of all dye classes are the azo dyes some of which are based on these amines. In addition, the problematic amines are sometimes present in dyes as contaminants, some of the manufacturing precursors to dyes are not always completely removed from the final dye product, or as a result of degradation due to light or high temperature during storage (5).

The dyes producing these banned amines such as benzidine based dyes have been prohibited from use and safer alternatives have been suggested for most of them. Unfortunately the available list of azo dyes is not exhaustive. Interestingly also, the dyes in use include many of examples of colourants whose environmental fate is unknown (5).

A good dye for use must be non-toxic or should have low toxicity (6). Dyes and pigments have to be screened for toxicity since they find their way into the human body through materials such as clothing, hair dye, and also by injestion (6). In order to minimize the possible damage to man and the environment, an international Association of Dyestuff Manufacturing industry (ETAD) was founded in 1974. ETAD coordinates the ecological and toxicological consequences of organic dyestuffs and pigments (7). Over the last two decades the synthetic dye industry has developed thorough health, safety and environmental standards to reduce negative impacts (8). However, there are still companies making carcinogenic dyes (8). The majority of garment production and fabric dying now takes place in developing countries. Often health and safety regulations are not well enforced with workers not using protective equipment or using banned products, which can be extremely damaging to health and wellbeing (8).

There are two types of toxicity test available-Acute toxicity by $\mathrm{LD}_{50}$ and by the Fixed Dose Procedure requiring fewer animals; the other method is the long -term toxicity test, which deals with the teratogenicity and carcinogenicity of the compounds (6). 
$\mathrm{LD}_{50}$ determination is a simple preliminary assessment of the toxicity of a compound by determination of the median lethal dose which is capable of killing $50 \%$ of animals under stated conditions (9). In terms of signs or symptoms, $\mathrm{LD}_{50}$ is redefined as the dose effective for producing a certain sign in $50 \%$ of the experimental animals (10).

The knowledge that some chemical substances including dyes are toxic gave birth to this study. Despite the tight security measure at the Nigerian seaports, airports and borders, banned products still find their way into the country and eventually the market (11). The study aims at identifying the dyes in the effluent of the textile company under study to ascertain its health and environmental consequences.

\section{Sampling Area / Sampling Technique}

The effluent used in this study was collected from General Cotton Mill, Onitsha, Anambra state located in the Eastern part of Nigeria. The company discharge its effluent directly into the river Niger and fishermen do fish in the river, close to the area of discharge.

The effluent was collected in accordance with 1999 APHA standard method of sampling wastewater. Every one hour a sample was collected at the same location (specific location) beneath the surface in a quiescent area within the effluent stream (typical near the centre of the effluent stream). Pre-cleaned plastic container was placed below the surface of the effluent with the mouth directed toward the current. The sample was immediately stored airtight and kept in a refrigerator preset at $4^{0} \mathrm{C}$. At the end of the day (24 hours) the composite sample was made up. Extraction of the dyes in the effluent was commenced immediately

\section{Materials And Method}

$\mathrm{T}$ he dyes were extracted from the effluent by means of solvent extraction (extraction in batches) using petroleum spirit (boiling range $40^{\circ} \mathrm{C}-60^{\circ} \mathrm{C}$ ). Multiple extractions with smaller portions of the same volume of solvent was achieved when after every agitation of the effluent, $150 \mathrm{ml}$ of the effluent was measured into the separatory funnel and equal volume $(150 \mathrm{ml})$ of the extracting solvent added to the separatory funnel and its content. Equilibration of the mixture was achieved by simple repeated inversion of the separatory funnel. At the end of each extraction, the organic phase was separated from the aqueous phase into a beaker. The solvent was allowed to evaporate while keeping the organic extract away from sunlight and heat. At the end of the extractions, the extract dye were added up.

After trial with different TLC plates and different eluting solvent/ solvent mixture, the extract dye was separated into its component by Thin Layer Chromatography on TLC plates coated with aluminium oxide (F254 type T) by means of solvent mixture; butan-1-ol: water: glacial acetic acid as the eluting solvent. With the aid of a pre- cleaned spatula, the extract dye components were each separately scrapped into a $250 \mathrm{ml}$ beaker, covered and kept out of sunlight and heat. The preparative thin layer was repeated severally to obtain enough quantity of each of the extract dye component. The scrapped components were each dissolved in the solvent mixture used to elute them and filtered into a beaker. The filtrate in a beaker was evaporated in a water bath leaving behind the solute.

Each component was subjected to UV visible determination using UV visible spectrophotometer ; Cam spec M 330 and Infrared spectroscopy using FTIR ATI Mattson genesis series to ascertain the wavelength of absorption and the functional groups present in each extract dye component.

\subsection{LD $D_{50}$ test}

To determine the acute toxicity $\left(\mathrm{LD}_{50}\right)$ test, a total of twenty adult male mice obtained from the animal house of the Department of Biochemistry, University of Nigeria, Nsukka, ranging in weight from $22.4 \mathrm{~g}$ to27.5g were used. The mice were weighed and separated into four groups of five adult male mice and put in different cages. They were fed with feeds and water for fourteen days (14) in order to acclimatize them to the environment. A calculated dose of a suspension of the extract dye ranging in values $200 \mathrm{mg} / \mathrm{kg}, 300 \mathrm{mg} / \mathrm{kg}$, $400 \mathrm{mg} / \mathrm{kg}$ and $500 \mathrm{mg} / \mathrm{kg}$ was dissolved in $1 \mathrm{ml}$ of Normal saline, thoroughly mixed and administered orally to the experimental mice according to their individual body weights. The mice were kept under strict observation for 24 hours. The factors observed, where death and sign on mice. After 24 hours there was no death or sign on the mice, the duration of the observation was extended to 48 hours, 72 hours and 96 hours. The percentage of the animal dead was calculated, corrected and converted to probit (probability units) (Akpuaka, 1990). A graph of probit against $\log _{10}$ dose was plotted and from there the $\mathrm{LD}_{50}$ was calculated.

\section{Results And Discussion}

The thin layer chromatographic separation, separated the extract dye into two components ; a blue and a purple coloured dye of $\mathrm{R}_{\mathrm{f}}$ values 0.78 and 0.86 respectively. It is likely that the blue and purple coloured dyes are not the only dyes present in the effluent, probably the right eluting solvent was not found to elute the other dyes present. 


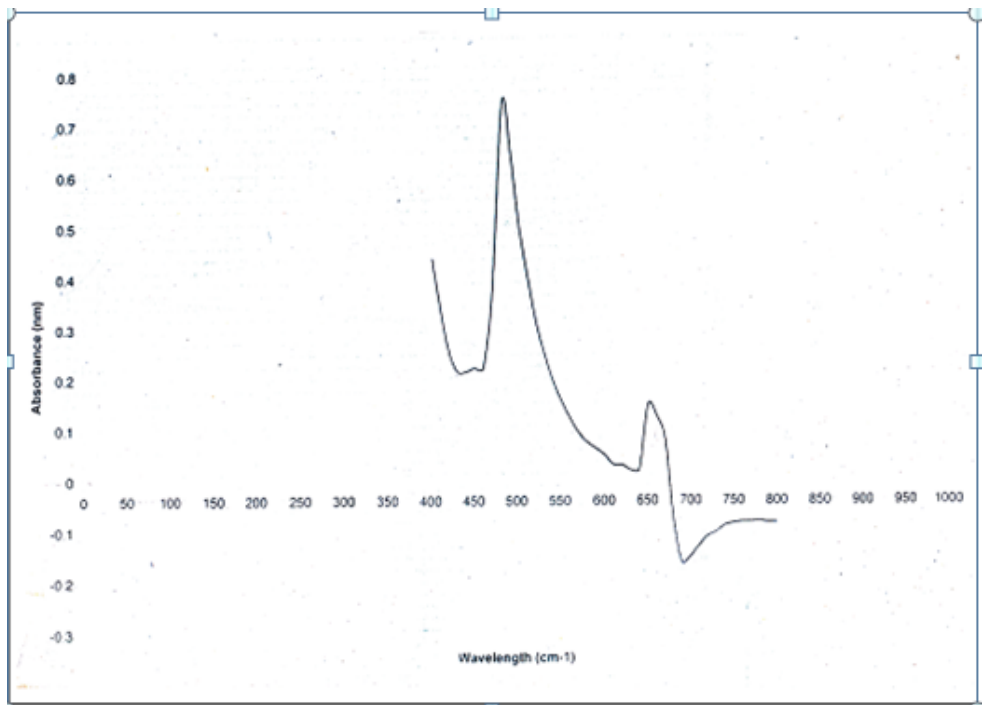

Figure 1: UV visible spectrum of blue coloured dye

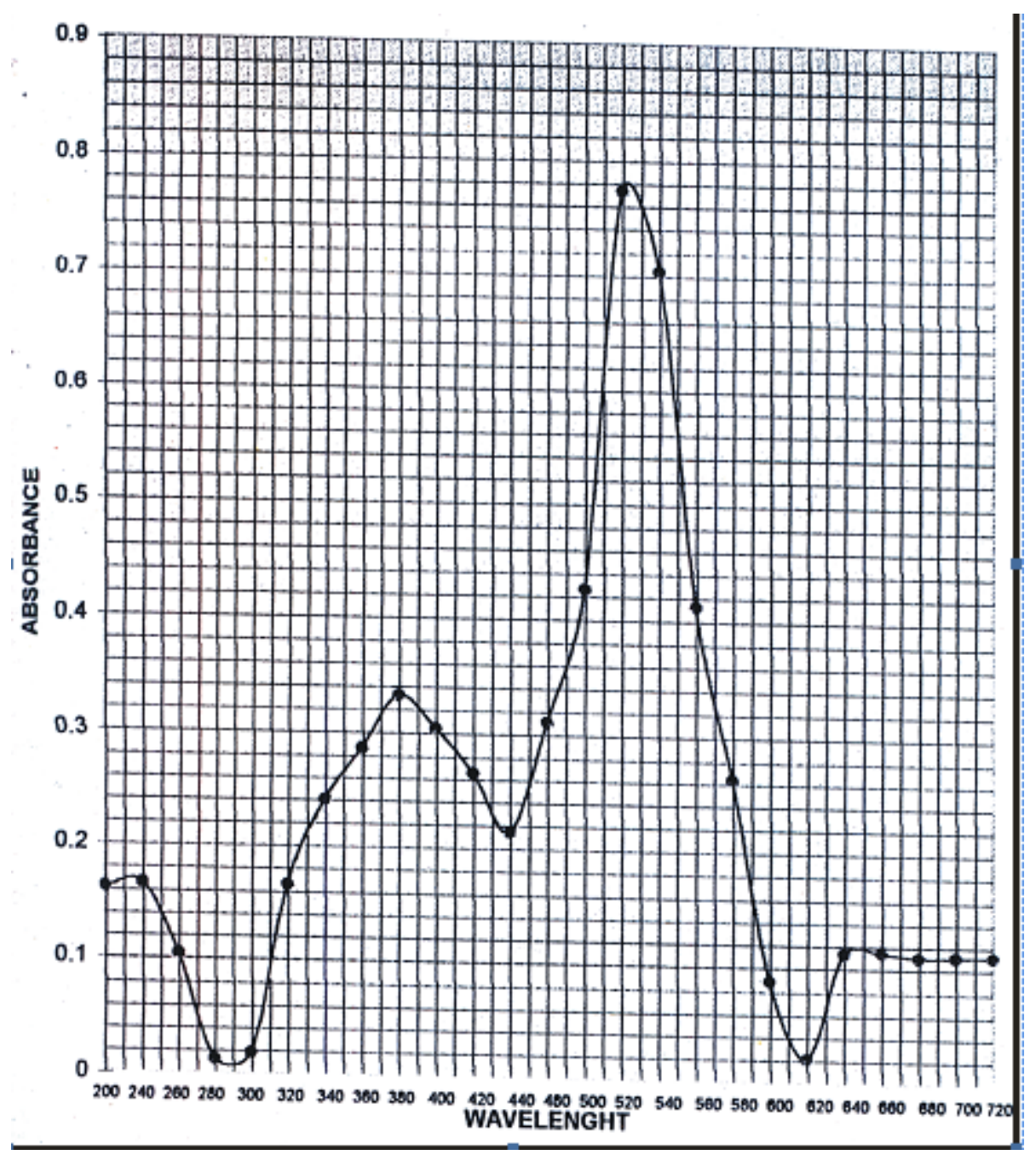

Figure 2: UV visible spectrum of purple coloured dye

Fig. 1 and 2 show the UV visible spectra of the blue and purple components of the extract dyes respectively. The wavelength of absorption of the blue coloured dye is $500 \mathrm{~nm}$ while that of the purple coloured dye is $520 \mathrm{~nm}$. The UV visible spectra result of both dyes could not be matched with that of a known dye. 


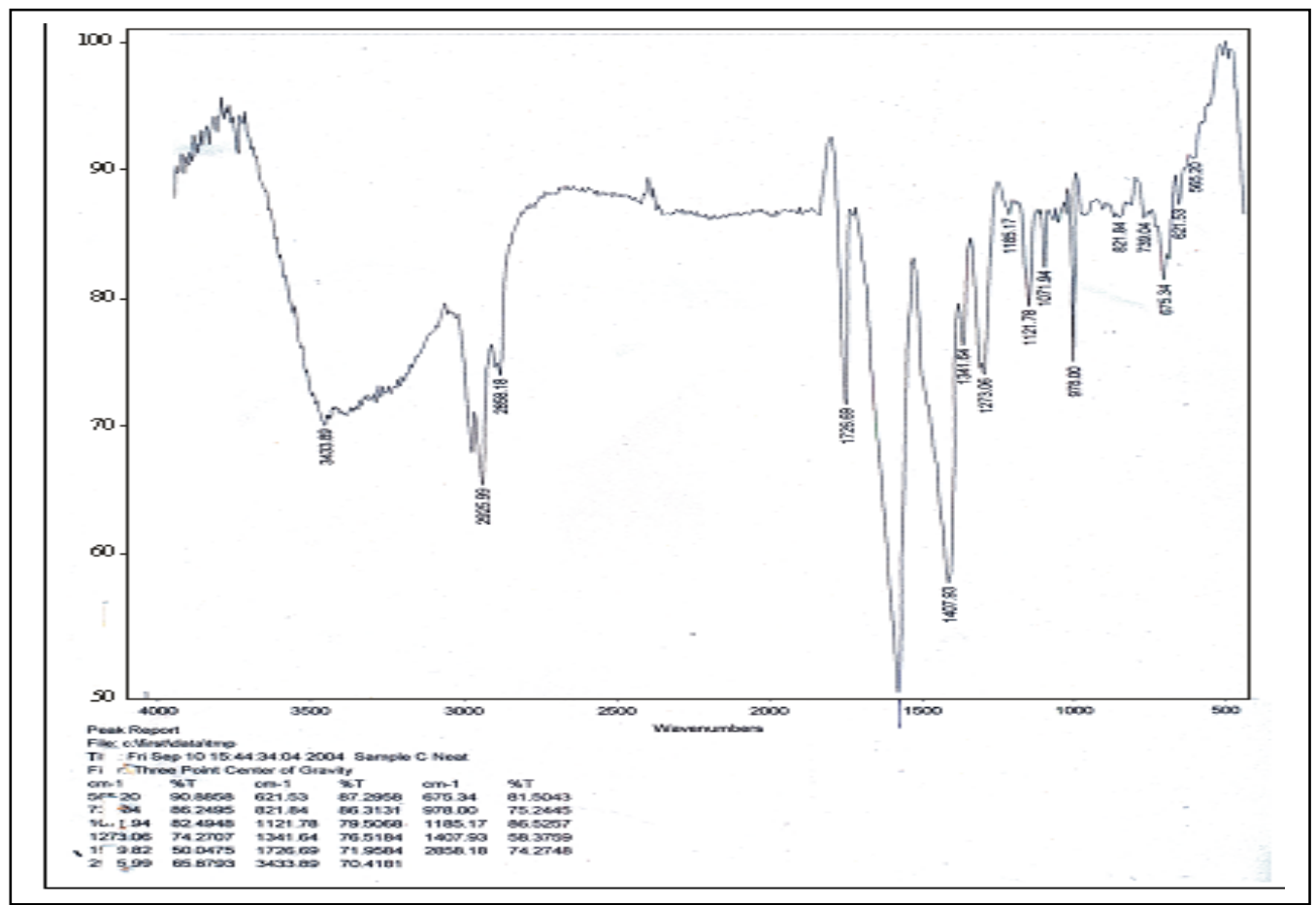

Figure 3: IR spectrum of blue coloured dye

Table 1: Frequency of Absorption of Blue Coloured Dye.

\begin{tabular}{|c|c|c|c|}
\hline Frequency $\mathrm{Cm}^{-1}$ & Appearance & Band & Compound \\
\hline 3433.89 & $\mathrm{M}$ & N-H Stretch & $\mathrm{NH}_{2}$ in primary amides \\
\hline 1726.69 & V.S & $\mathrm{C}=\mathrm{O}$ Stretch & $\begin{array}{l}\text { Saturated Ketones and saturated aldehydes } \\
\text { Amines }\end{array}$ \\
\hline 1500 & V.S & $\mathrm{N}-\mathrm{H}$ bend & Alkenes \\
\hline 1407.93 & V.S & $\mathrm{C}-\mathrm{H}$ in plane bend & Aromatic amines \\
\hline 1341.64 & $\mathrm{~S}$ & $\mathrm{C}-\mathrm{N}$ Stretch (aryl) & Aromatic amines \\
\hline 1273.06 & M & $\mathrm{C}-\mathrm{N}$ Stretch & Aromatic amines \\
\hline 1185.17 & $\mathrm{~S}$ & $\mathrm{C}-\mathrm{N}$ Stretch & Amines or $\mathrm{C}-\mathrm{OH}$ in secondary or tertiary \\
\hline 1121.78 & $\mathrm{~S}$ & $\begin{array}{l}\mathrm{C}-\mathrm{C}-\mathrm{N} \text { bending in amines or } \\
\mathrm{C}-\mathrm{O} \text { bend }\end{array}$ & alcohols \\
\hline & & $\mathrm{C}-\mathrm{N}$ Stretch & $\mathrm{SO}_{3} \mathrm{H}$ in sulphonic acids \\
\hline 1071.94 & S & $\mathrm{SO}_{3}$ Sym Stretch & $\mathrm{CH}-\mathrm{CH}_{2}$ in vinyl compounds \\
\hline 978 & V.S & $\mathrm{CH}_{2}$ out of plane wag & Alkyl Chlorides \\
\hline 675.34 & M & C - Cl Stretch & Alkyl Chlorides \\
\hline 621.53 & M & $\mathrm{C}-\mathrm{Cl}$ Stretch & \\
\hline
\end{tabular}




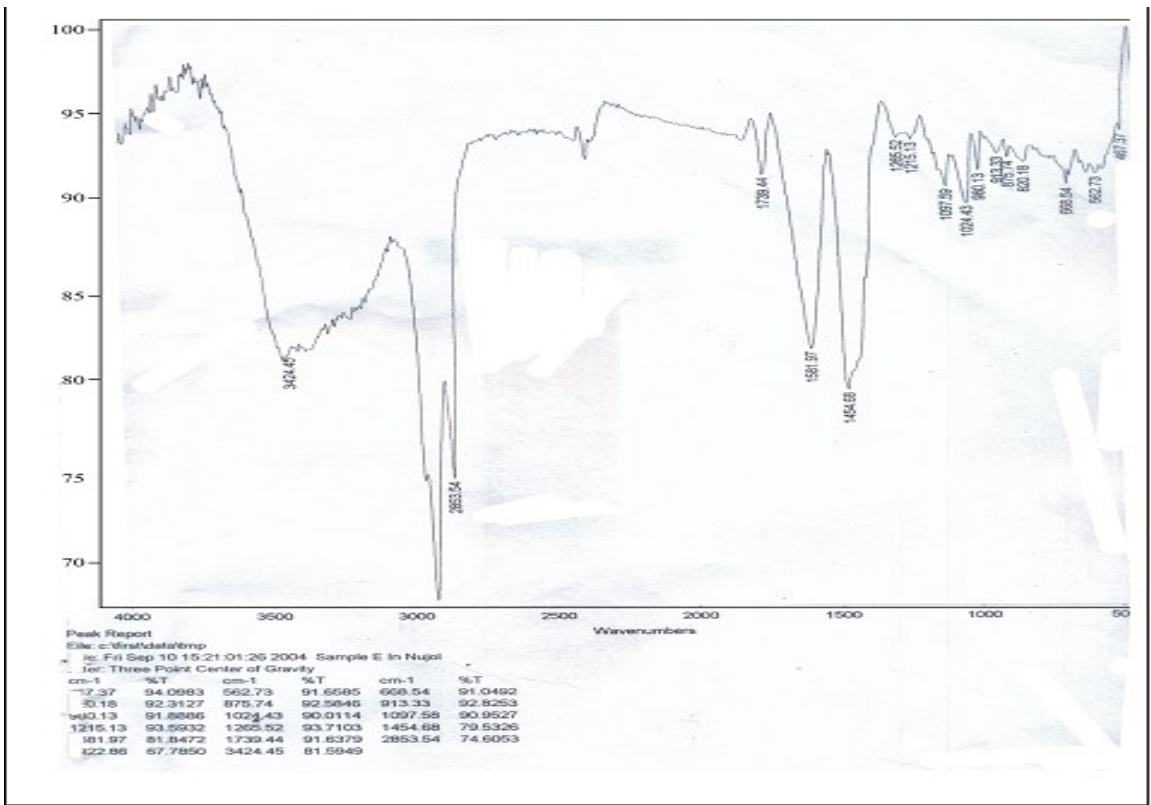

Figure 4: IR spectrum of purple coloured dye

Table 2: Frequency of Absorption of Purple Coloured Dye.

\begin{tabular}{|c|c|c|c|}
\hline Frequency $\mathrm{Cm}^{-1}$ & Appearance & Band & Compound \\
\hline 3424.45 & $\mathrm{M}$ & N-H Stretch & $\begin{array}{l}\mathrm{NH}_{2} \text { in aromatic amines, primary amines and } \\
\text { amides }\end{array}$ \\
\hline 3000 & V.S & C - H Stretch & Aromatics \\
\hline 2853.54 & $\mathrm{~S}$ & $\mathrm{C}-\mathrm{H}$ Stretch & \\
\hline 1739.44 & V.S & $\mathrm{C}=\mathrm{O}$ Stretch & $\begin{array}{l}\text { Saturated ketones and saturated aldehydes } \\
\text { Amines or Azo }\end{array}$ \\
\hline 1589.71 & $\mathrm{~S}$ & $\mathrm{~N}-\mathrm{H}$ bend or $\mathrm{N}=\mathrm{N}$ & \\
\hline 1454.68 & $\mathrm{~S}$ & & Amines \\
\hline 1097.56 & $\mathrm{~s}$ & $\mathrm{C}-\mathrm{N}$ Stretch & $\mathrm{CH}=\mathrm{CH}_{2}$ in vinyl compounds \\
\hline 1024.43 & $\mathrm{~S}$ & $\mathrm{C}-\mathrm{H}$ out of plane deformation & \\
\hline 980.13 & $\mathrm{~S}$ & $\begin{array}{l}\mathrm{C}-\mathrm{H} \text { out of plane deformation } \\
\mathrm{C}-\mathrm{Cl} \text { Stretch }\end{array}$ & $\mathrm{CH}=\mathrm{CH}_{2}$ in vinyl compounds \\
\hline 668.54 & $\mathrm{~m}$ & & Alkyl Chlorides \\
\hline
\end{tabular}

Fig. 3 and 4 are the IR spectra of the extract dye components while TABLES 1 and 2 are the functional groups corresponding to the frequency of absorption identified in the IR spectra of the dyes. Both tables reveal the presence of primary amides $\left(\mathrm{RCONH}_{2}\right)$, vinyl group $\left(-\mathrm{CH}=\mathrm{CH}_{2}\right)$, aromatic amine, sulphonic acid group ($\left.\mathrm{HSO}_{3}\right)$, alkyl chloride $(\mathrm{C}-\mathrm{Cl})$ and saturated ketones .

The identified functional groups are in consonant with the functional groups found in most fiber reactive dyes. Comparatively, acid dyes are normally very large aromatic molecules consisting of many linked rings. They usually have a sulfo or carboxy group on the molecules making them soluble in water (14). Basic dyes consist of aminos or alkyl amino groups $\left(-\mathrm{NR}_{3}+\right.$ or $\left.=\mathrm{NR}_{2}{ }^{+}\right)$as their auxochromes (15). Direct dyes are almost always azo dyes with some similarities to acid dyes. They also have sulphonate functionality (16). Vat dyes come exclusively from the carbonyl class of dyes (16). Mordant dyes are dichromates and chromium complexes (17). Disperse dyes are mostly made of azo class (amino azobenzene, heterocyclic amino azobenzene,disazo), other than these are the carbonyl class, and a few from the nitro and plymethine classes (18). The structure of azo dyes is based on azobenzene, $\mathrm{ph}-\mathrm{N}=\mathrm{N}-\mathrm{ph}$. Little is know about the structure of sulphur dyes and therefore they are classified according to the chemical structure of the starting material. Dry organic starting material is heated with sulphur between 160 and $320 \mathrm{C}$ producing a polysulphide bake $(19,20)$. Fiber reactive dyes are those dyes which contain a functional group capable of forming a covalent chemical bond with a fiber. The component of a fiber reactive dye are four ; the chromogen (usually an azo, carbonyl i.e anthraquinone or phthalocyanine), the water solubilizing group (ionic groups, often sulphonate salts), the bridging group which frequently is an amino, $-\mathrm{NH}$ - group and the fiber reactive group which is the only part of the molecule able to react with the fiber; this is usually a haloheterocycle (often chlorotriazine) or an activated 
double bond which form covalent bonds with the hydroxyl groups of cellulosic fibers, amino or amino, hydroxyl and mercapto groups of protein fibers and with the amino groups of polyamides $(7,21,22)$.

The identified functional groups in the IR spectra of both dyes are found in the structure of most reactive dyes. The sulphonic acid group used to impact solubility to most dyes is present in most fiber reactive dyes. The presence of the alkyl chloride $(\mathrm{C}-\mathrm{Cl})$ group reveals reactive site attached to most fiber reactive dye.

After the administration of the extract dye on the experimental mice there was no death or sign observed from 0 hour to 24 hours. The duration of observation was increased to 48 hours, 72 hours and 96 hours, there was still no sign or death observed on the experimental mice. TABLE 3 and Fig. 5 shows the result of the plot of probits of percentage deaths for each group of mice against $\log _{10}$ dose of each group. $L D_{50}$ is usually the $\log _{10}$ dose corresponding to probit 5 on the graph, but, because there was no observed sign or death the maximum probit was 3.36. The dyes contained in the effluent investigated are non toxic, because in an $\mathrm{LD}_{50}$ toxicity test done on 4461 colourants, no toxicity was quoted for 44 colourants which had $\mathrm{LD}_{50}<250 \mathrm{mg} / \mathrm{kg}$ while 3669 exhibited practically no toxicity i.e. $\mathrm{LD}_{50}$ above $250 \mathrm{mg} / \mathrm{kg}(6,7)$. Since the doses of $300 \mathrm{mg} / \mathrm{kg}, 400 \mathrm{mg} / \mathrm{kg}$ and $500 \mathrm{mg} / \mathrm{kg}$ of the extract dye used in the $\mathrm{LD}_{50}$ test caused no signs or death of the experimental mice, it concludes that the dyes are non toxic. Moreover, of the various types of dyes used for dyeing, fiber reactive dyes may be considered as the best suited range for ecofriendly processing $(22,23,24)$.

Table 3: LD ${ }_{50}$ Determination of Dye Extract

\begin{tabular}{|c|c|c|c|c|c|c|c|}
\hline Group & No in cage & Dose $\mathrm{mg} / \mathrm{kg}$ & $\log _{10}$ dose & $\begin{array}{l}\text { No. of animals } \\
\text { dead }\end{array}$ & $\begin{array}{l}\% \text { of animals } \\
\text { dead }\end{array}$ & $\begin{array}{ll}\% & \text { of } \\
\text { correction }\end{array}$ & $\begin{array}{l}\text { Probit } \\
\text { corresponding to } \% \\
\text { animal dead }\end{array}$ \\
\hline 1 & 5 & 200 & 2.30 & 0 & 0 & 5 & 3.36 \\
\hline 1 & 5 & 300 & 2.47 & 0 & 0 & 5 & 3.36 \\
\hline 1 & 5 & 400 & 2.60 & 0 & 0 & 5 & 3.36 \\
\hline 1 & 5 & 500 & 2.70 & 0 & 0 & 5 & 3.36 \\
\hline
\end{tabular}

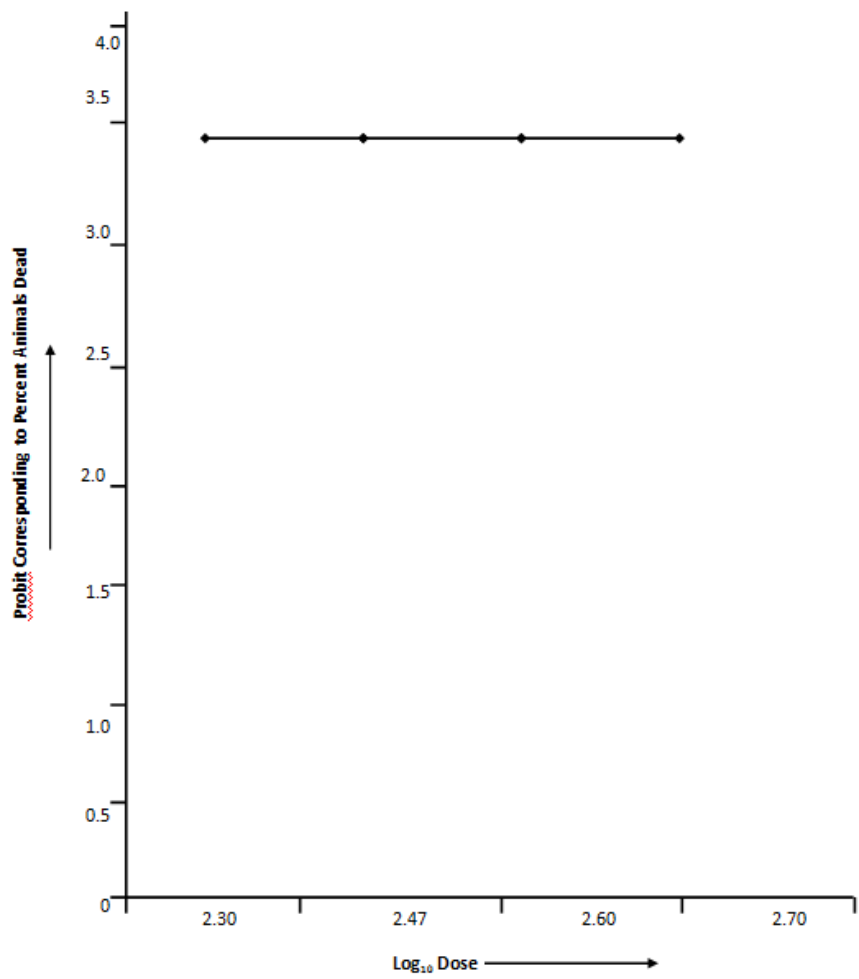

Figure 5: Toxicity Determination in Mice Graph of Probit \% Animal Dead against $\log _{10}$ Dose of Dye Extract

\section{Conclusion}

The IR spectra of the dyes separated from the dye extract obtained from the effluent of the textile mill investigated revealed the presence of most of the functional groups found in most fiber reactive dyes. In addition to other functional groups identified, the presence of alkyl chloride group $(-\mathrm{C}-\mathrm{Cl})$ in each of the dyes indicate that the dyes are fiber reactive dyes. The acute toxicity test $\mathrm{LD}_{50}$, show that the dyes in the effluent are non toxic. This supports the finding on fiber reactive dyes as ecofriendly dyes . 


\section{References}

[1]. What is Dye, http://foodcolorworld.com/what-is-dye.html, accessed 30/7/ 13

[2]. Types of $\begin{array}{llllll}\text { Dyes } & - & \text { Classification } & \text { Based } & \text { Ch } & \text { Chemical }\end{array}$ http://www.textileschool.com/School/TextileFinishing/TypesofDyes.aspx., accessed. 2/8/13

[3]. Dyes, http://en.wikipedia.org/wiki/Dye, accessed 2/8/13

[4]. Kirk Othmer Encyclopedia of Chemical Technology , $4^{\text {th }}$ Edition, Vol 8, John Wiley \& Sons, New York.

[5]. A. Reife and H. Freeman, Environmental chemistry of dyes and pigments (New York: John Wiley and Sons Inc.,1996).

[6]. C. O. Okafor and M. U. Akpuaka, Acute Toxicity Determination of Two New Benzothiazinophenoxazine Dyestuff in Mice, j. Exp \& Clin. Anat., 2(2), 2003, $20-23$.

[7]. H. Zollinger, Colour chemistry (Weinheim: VCH, 1991).(2)

[8]. Ethical Fashion Forum, www.ethicalfashionforum.com/the-issues/dyes, accessed 2/8/13

[9]. A. Goldstein, I. Anonov and S. Kalman, Principles of drug action : the basis of pharmacology (New York : John Wiley and Sons Inc, 1974). (2)

[10]. B. B. William, D.O.Gary and A.V.Gray, Clinical and diagnostic veterinary toxicology (Iowa, Kendall/Hunt Company, 1976).,(2)

[11]. O. Jide, (2013),Policing our porous borders, Nigeria intel online, $3^{\text {rd }}$ april, available at www.nigeriaintel.com/2013/04/03/policingour-porous-borders, accessed 6/4/2013

[12]. Standard Methods for The Examination of Water and Wastewater By American Public Health Association, American Water Works Association, Water Environment (1999), $20^{\text {th }}$ Edition.

[13]. M. U. Akpuaka, Synthesis and application of some new types of heterocyclic dyes, University of Nigeria, Nsukka, Ph.D, 1990

[14]. Acid dye, http://en.wikipedia.org/wiki/Acid-dye, 1/8/13

[15]. Basic Dyes - Dyestuff, Colors, Chemicals, Coloring material, Foods, www.dyes-pigments.com/basic-dyes, accessed 5/8/13

[16]. Chemistry of Dyes, www.chm.bris.ac.uk/webprojects2002/price/cellulose.htm, accessed 1/8/13

[17]. Mordant Dye, http://www.britannica.com/EBchecked/topic/391966/mordant-dye accessed 2/8/13

[18]. Synthetic Textile Dyes, http://www.chm.bris.ac.uk/webprojects2002/price/synthetic.htm , accessed1/8/13

[19]. Sulfur Dyes, http://www.scribed.com/doc/30109405/Sulfur-Dyes, accessed 5/8/13

[20]. Kirk Othmer Encyclopedia of Chemical Technology, 2nd Edition, Vol 7, John Wiley and Son ,New York, pp $630-636$

[21]. Reactive Dye, http://en.wikipedia.org/wiki/Reactive - dye, accessed 4/8/13

[22]. www.naturallysaferproducts.com/?tag=fiber-reactive-dyes, accessed 5/10/13

[23]. www.connection.ebscohost.com/c/articles/23575834/reactive-dyes-are-more-eco-friendly-than-other-dyes Accessed 6/10/13

[24]. www.oecotextiles.wordpress.com/2009/09/01/dyes-synthetic-and-natural accessed 6/10/13

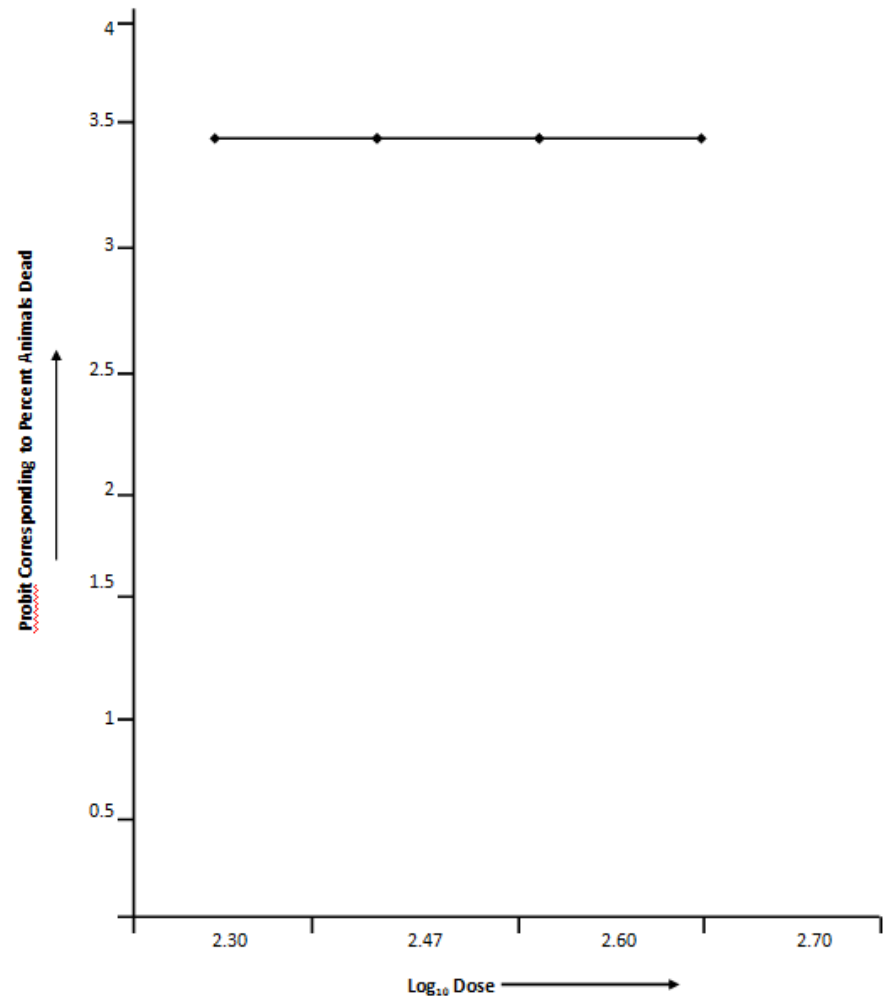

Figure 5: Toxicity Determination in Mice Graph of Probit \% Animal Dead against $\log _{10}$ Dose of Dye Extract 